\title{
ПРАВОВОЕ РЕГУЛИРОВАНИЕ БАНКРОТСТВА С ДРЕВНИХ ВРЕМЕН И ПО НАШЕ ВРЕМЯ
}

\author{
(c) 2019 Майрбеков Султанбек Саламуевич \\ Студент-магистрант юридического факультета \\ Чеченский государственный университет, Чеченская Республика, Грозный \\ E-mail: berserk955@mail.ru \\ (c) 2019 Ибрагимов Юсуп Муслимович \\ ассистент кафедры теории и технологии социальной работы \\ Чеченский государственный университет, Чеченская Республика, Грозный \\ E-mail: yusuf_ibr@mail.ru
}

В статье анализируются правовые аспекты регулирования банкротства, эксплицируется порядок распределения имущества между кредиторами несостоятельного должника и признаки несостоятельности должников. Также показано, как в советский период исчезает сама категория несостоятельности, возрождение которой в российском праве пришлось лишь на 1992 год.

Ключевые слова: долг, банкротство, несостоятельность, должник, кредитор.

О зарождении института несостоятельности в качестве института гражданского, торгового и процессуального можно говорить еще в контексте римского права. Как раз в Древнеримском государстве особое внимание было направлено на возврат долга и использовались правовые методы разрешения конфликта в случаях, когда должник не исполнял свои обязательства. В первую очередь, акцент делался непосредственно на личность должника. Неисправным должникам полагался 30-дневный срок для возврата долга кредитору. В случае неоплаты, не получивший денег кредитор приступал к судопроизводству посредством наложения руки.

В дальнейшем происходил ступенчатый, последовательный переход от личного взыскания к имущественному. Например, как следует из исследования Свириденко О.М., в 411 или 428 г. до н.э. был издан закон Петелия, регламентирующий перевод взыскания с личности должника на имущество последнего. Кредиторы не исполняющего обязательства должника, получали от претора полномочия вступить во временное обладание его имуществом. Имущество продавалось с учетом определенных формальностей посредством публичных торгов. Если же и после этого имелся недостаток денежных средств для полного удовлетворения кредиторов, последние получали платежи по соразмерности [12].

Также, как и в мировой истории, в истории нашей страны институт несостоятельности (банкротства) зародился довольно давно. Ряд материально-правовых и процессуальных положений конкурсного права можно увидеть уже в Русской Правде.

Как считает В.С. Каменков, «зачатки конкурсного процесса были не чужды древнейшему законодательству России» [2, с.39].

Статьи 68 и 69 Русской Правды содержат определение понятия несостоятельности и ее видов, а именно несчастной несостоятельности, то есть наступившей независимо от вины должника, и несостоятельности по его вине. Данные статьи также регламентируют порядок распределения имущества между кредиторами несостоятельного должника. Также, Русская Правда регулирует случаи злонамеренной несостоятельности, которая выражается в бегстве должника от кредиторов.

Зачатки конкурсного права можно также найти и в договорах смоленского князя Мстислава 1229 г. с Ригой, Готландом и рядом немецких городов.

В московский период истории Руси, по мнению В.С. Каменкова, конкурсное право никак не изменилось [10, с.41].

Очередным этапом развития российского конкурсного права можно назвать издание в 1729 г. Вексельного устава. Возникла необходимость законодательно закрепить определение несостоятельности, что и было осуществлено в данном Уставе, который выделял признаки несостоятельности. К таким признакам необходимо отнести «неисправность в платежах», «поте- 
рю имущества», «бегство должника».

Тем не менее, законное определение несостоятельности нельзя было назвать достаточно определенным, а в рамках практического применения требовалось наличие четких, конкретных критериев для признания должников несостоятельными. В целях разрешения этой проблемы использовалось иностранное законодательство, в котором конкурсное право нашло большее развитие, чем в нашей стране. В Российском же государстве, о чем свидетельствуют различные источники, в частности труд Беляева И.Д., издавали отдельные указы с целью усовершенствовать существующее законодательство о банкротстве [7].

Следующим этапом в становлении российского конкурсного законодательства, о чем говорится в работе Карелиной С.А., можно назвать принятие Устава о банкротах 19 декабря 1800 года. Структура данного устава состояла из двух частей, регулирующих два вида несостоятельности, то есть, торговую или купеческую, а также несостоятельность дворян. Те субъекты, которые не были в состоянии выплатить свои долги, параграфами устава 87 и 98 признавались банкротами [11].

Таким образом, Устав о банкротах предполагал, что главным признаком несостоятельности должников является неплатежеспособность. Российское законодательство рассматриваемого периода выделяло виды несостоятельности в зависимости от вины должника, называя, соответственно, упадшую, то есть наступающую ввиду отсутствия вины должника, неосторожную, то есть наступающую в связи с неосторожной виной должника или же по небрежности, злостную несостоятельность, специфической чертой которой являлся подлог со стороны должника, то есть наличие умышленной вины последнего в наступлении неблагоприятных имущественных последствий.

Осуществление производства над имуществом несостоятельного должника велось по инициативе либо самого должника, либо же его кредиторов и во всех случаях характеризовалось заключением должника под стражу, что говорит о личном характере ответственности должника, а также и об определенном уровне неразвитости конкурсного законодательства.

В уставе о банкротах стечение нескольких кредиторов для введения конкурсного производства не признавалось существенным. Исхо- дя из вида несостоятельности, могло наступить и освобождение должника под поручительство кредиторов и так далее.

На период процесса конкурсного производства над имуществом должника назначался куратор, функцией которого являлось, в том числе, уточнение размера конкурсной массы. В ходе распределения конкурсной массы, имея особое положение в России того времени, церковь пользовалась преимущественным правом на удовлетворение собственных требований. Требования остальных кредиторов подлежали удовлетворению по соразмерности.

Тем не менее, уже в 1832 году был принят новый Устав о несостоятельности, заменивший первую часть Устава о банкротах. Как считает В.С. Каменков, в Уставе не уделялось должного внимания материально-правовым проблемам конкурсного права, в связи, с чем его содержание можно оценить, как неудовлетворительное [10 c. 42$]$.

Уставом судопроизводства торгового 1832 года регламентировались вопросы торговой несостоятельности. Статья 386 Устава заключала в себе легальное определение несостоятельности: «Торговой несостоятельность признается, когда кто-либо по торговле, присвоенной лицам, взявшим купеческие или промысловые свидетельства, придет в такое дел положение, что не только не имеет наличных денег на удовлетворение в срок своих долгов в важных суммах, более 1500 рублей, но и есть признаки, в сем разделе определенные, по коим заключить можно, что долги его неоплатны, то есть всего имущества его для полной их уплаты будет недостаточно» [11].

Также, как и торговая несостоятельность в русском дореволюционном законодательстве регулировалась и состоятельность неторговая. Субъектами неторговой несостоятельности выступали дворяне. Предпосылкой для введения конкурсного производства в случаях неторговой несостоятельности служила неоплатность должника.

Торговую и неторговую несостоятельность следует различать по основаниям введения конкурсного производства, по подсудности, а также по правовому регулированию. Согласно позиции Г.Ф.Шершеневича, русское конкурсное законодательство изучаемого периода в данном смысле являлось несовершенным, двойной конкурс только усложнял задачу [13].

Управление делами несостоятельного долж- 
ника, как говорится в работе Васьковского Е.В., входило в компетенцию присяжного попечителя из числа указанных кредиторами «посторонних благонадежных лиц» или же из числа присяжных и частных поверенных [8].

Вследствие превышения суммы обозначенных кредиторами требований половины пассива должника присяжный попечитель был обязан созвать собрание кредиторов с целью избрания конкурсного управления.

Законодательное определение конкурсного управления можно найти в ст. 459 Устава о несостоятельности: «Конкурсное управление принимает в свое распоряжение все дела несостоятельного и в качестве уполномоченного от всех заимодавцев управляет оным в пользу их, как доброму хозяину свойственно».

В конкурсное управление входили председатель и кураторы, избираемые большинством голосов из числа кредиторов или посторонних лиц, которые озвучили свое согласие на избрание. Избрание лиц, уже состоявших председателями и кураторами в двух других конкурсах не допускалось. По мнению Е.В. Васьковского, «с утверждением состава конкурсного управления деятельность присяжного попечителя прекращается и возникает конкурсное производство в тесном смысле слова» [8].

Главными целями конкурсного управления можно было назвать формирование конкурсной массы, оценка последней и ее распределение между кредиторами. Согласно этим целям конкурсное управление производит розыск имущества несостоятельного должника, осуществляет взыскания по обязательствам третьих лиц, имеет правомочие на выкуп заложенного имущества для обращения последнего в конкурсную массу, а кроме того осуществляет оспаривание сделок должника, которые он совершил в ущерб кредиторам.

По итогам установления всей совокупности долгов несостоятельного должника конкурсное управление распределяет их согласно степени достоверности на три группы.

Итак, в соответствии с этим можно выделить три вида долгов несостоятельного должника:

1) бесспорные, то есть такие долги, которые основаны на очевидных и неопровержимых документах, таких как, например, на векселях, посредством которых осуществлен протест, договорах купли-продажи недвижимости с рассрочкой платежа, и иных документах, которые допускаются к участию в конкурсе беспрекословно;

2) спорные долги, которые допускаются к участию в конкурсе с большой долей условности и могут быть оспорены со стороны должника;

3) недействительные долги, которые допустить к конкурсу нельзя, например, такие долги, по которым истек срок исковой давности.

За установлением долгов следовало составление общего счета, а также плана удовлетворения долгов, в котором последние подразделялись на четыре разряда: 1) первый разряд, включающий долги, которые подлежат удовлетворению как сполна (денежные средства церкви), так и по соразмерности (например, казенные недоимки, долги, заработная плата); 2) ко второму разряду относились долги, подлежащие удовлетворению по соразмерности, например бесспорные казенные долги; 3) третий разряд включал долги, которые подлежали предварительному судебному рассмотрению; 4) к четвертому разряду относили долги, которые не были предъявлены кредиторами в необходимые сроки.

В дальнейшем, конкурсное управление включало в себя заключение о причинах несостоятельности, а также установление ее вида, которым могла быть несчастная несостоятельность, простое банкротство и злонамеренное банкротство.

В случае неосторожной несостоятельности, а также и злостного банкротства существовала возможность обращения взыскания на имущество, которое должник получал после окончания конкурсного производства, в отличие от несчастной несостоятельности, согласно которой долги погашались по окончании конкурса. В рамках несчастной несостоятельности кредиторы имели право предоставить должнику часть конкурсной массы. Злостная несостоятельность по своей сути обусловлена умыслом со стороны должника. Злостный банкрот подлежал уголовному суду, а в случае его оправдания он все равно нес гражданско-правовую ответственность.

Затем, в начале XX века в Российской империи был подготовлен проект Устава о несостоятельности.

Несостоятельность, в качестве главной категории конкурсного права можно наблюдать и в ГК РСФСР 1922 года [6], а именно в договорах займа, поручения, в главе посвященной юридическим лицам. Тем не менее, в первых советских законах конкурс, как таковой, и не упоминался. 
Причиной этого являлся тот факт, что конкурсное производство не может осуществляться в рамках командной экономики, и, таким образом, противоречит советской правовой системе.

Учитывая данный факт, регулирование ликвидации юридических лиц в связи с их несостоятельностью осуществлялось на совсем иной основе, кардинально отличающейся от конкурса.

Ликвидацию несостоятельных юридических лиц осуществляла ликвидационная комиссия или же ликвидаторы, которые представляли государственные интересы.

Практика признания судами частных юридических лиц банкротами была довольно широко распространена, в отличие от случаев признания банкротами государственных предприятий, которые были редкостью. Кроме того, в процессе их ликвидации не обращалось взыскание на основные средства, в связи, с чем ликвидация не влекла за собой переход основного имущества социалистических организаций к их кредиторам.

Габов А.В. в своем исследовании пишет о том, что спустя некоторое время законодательно признали недопустимость ликвидации несостоятельных государственных предприятий: «Единство государственной социалистической собственности и плановый характер советского хозяйства несовместимы с признанием возможности ликвидировать государственное предприятие по мотивам несостоятельности, по требованиям кредиторов. Это противоречило бы плановой организации социалистического хозяйства» [9].

За счет реформы, которая была осуществлена в 1960-х гг., из советского гражданского права исчезла сама категория несостоятельности, несмотря на то, что в дальнейшем даже принимались нормативные акты, в которых использовалось рассматриваемое основание для ликвидации юридических лиц. В частности, здесь необходимо упомянуть Постановление СМ РСФСР от 24 сентября 1958 года, утвердившее, так называемый, Примерный устав дачно-строительного кооператива [5].

Возрождение института несостоятельности в российском праве пришлось на 1992 год, в связи с принятием Закона РФ № 3929-1 «О несостоятельности (банкротстве) предприятий» [4].

Необходимо сказать, что в процессе подготовки данного Закона был заимствован опыт законодательного регулирования отношений с неплатежеспособным или несостоятельным субъектом в рамках правовой системы США. Данным законом, помимо процедуры конкурсного производства были введены также и процедуры санационного типа, такие как процедура санации и процедура внешнего управления, отнесенные законодателем к реорганизационным процедурам.

В 1998 году был принят Федеральный закон № 6-Ф3 «О несостоятельности (банкротстве)» [3]. Уже после финансового кризиса приняли Федеральный закон от 8 июля 1999 г. № 144-Ф3 «О реструктуризации кредитных организаций» [2], а в дальнейшем и Федеральный закон от 25 февраля 1999 г. № 40-Ф3 «О несостоятельности (банкротстве) кредитных организаций» [1].

Дальнейшим шагом в реформировании законодательства о несостоятельности стал Закон о банкротстве, который был принят в 2002 году.

\section{Библиографический список}

1. Федеральный закон от 25.02.1999 № 40-ФЗ «О несостоятельности (банкротстве) кредитных организаций» // СЗ РФ, 1999, № 9, ст. 1097 (утратил силу)

2. Федеральный закон от 08.07.1999 № 144-Ф3 «О реструктуризации кредитных организаций» // СЗ РФ, 1999, № 28, ст. 3477 (утратил силу)

3. Федеральный закон от 08.01.1998 № 6-ФЗ «О несостоятельности (банкротстве)» // СЗ РФ, 1998, № 2, ст. 222 (утратил силу)

4. Закон РФ от 19.11.1992 № 3929-1 «О несостоятельности (банкротстве) предприятий» // «Российская газета», № 279, 30.12.1992. (утратил силу)

5. . 37 Примерного устава дачно-строительного кооператива, утв. Постановлением СМ РСФСР от 24 сентября 1958 г. // СП РСФСР. 1958. № 13. Ст. 154. (утратил силу)

6. Постановление ВЦИК от 11.11.1922 «О введении в действие Гражданского кодекса Р.С.Ф.С.Р.» (вместе с «Гражданским кодексом Р.С.Ф.С.Р.») // «Известия ВЦИК», № 256, 12.11 .1922 (утратило силу)

7. Беляев И.Д. История русского законодательства: Учеб. для студентов вузов, обучающихся по юрид. спец. / МВД России. С.-Петерб. ун-т. СПб.: Лань, 2015. 
8. Васьковский Е.В. Учебник гражданского процесса. М., 1917.

9. Габов А.В. Ликвидация юридических лиц. История развития института в российском праве, современные проблемы и перспективы. М.: Статут, 2011.

10. Каменков В.С. История развития законодательства о банкротстве в России и Беларуси // Безопасность бизнеса. 2009. № 3.

11. Карелина С.А. Правовое регулирование несостоятельности (банкротства): Учебно-практическое пособие. М.: Волтерс Клувер, 2006.

12. Свириденко О.М. Зарождение институтов конкурсного процесса в римском праве // «Журнал российского права», 2005, № 6

13. Шершеневич Г. Ф. Курс торгового права. М., 2003. Т. 4. С. 171-180. 